\title{
Social Construction of the Value of Education among the Disadvantaged Group: A Case Study of the Mahashas of Jammu and Kashmir State of India
}

\author{
Ms Amithy Jasrotia \\ Ph. D scholar, IIT Kanpur \\ Indian Institute of technology Kanpur, India.
}

\section{Doi:10.5901/ajis.2013.v2n11p34}

\begin{abstract}
The present paper extends the ongoing debate on the social construction of the value of education among poor in South Asia. The prime objective of this study is to explore the meanings and value of education that man and women of Mahashas attach to 'being educated'. To explore the research questions this study relies on qualitative methods by using narratives as a method of an enquiry. The theoretical framework of the study based on two broad aspects that is social constructionism and Bourdieu's theory of cultural capital. Fieldwork reveals that Mahashas are having faith in education and its benefits, despite the fact that majority of the poor population of India is losing faith in education due to high cost and low and uncertain results. However, the level of their aspirations and motivations is not found to be strong. It is also observed that there are noticeable gender differences in the perceptions and meanings of education. The Mahasha women believe that formal education during present times may not be of much benefit in terms of secure jobs but it is the only source for experiencing social mobility in life especially for the people belonging to the lowest rung. For them formal education is the only mean to have 'cultural and social distinction'. However, men give more importance to employment and wages in terms of 'market experiences' believing that spending on education is just a waste of money and time.
\end{abstract}

Keywords: Social construction of value of education, cultural and social distinction and market experiences.

\section{Introduction}

The focus in sociology of education in Twenty-first century has shown the shift from narrow domain of 'human capital' to the conceptual understanding of meaning of education. The effort has been raised to find out the meanings people attached to 'being educated' (Jeffrey, et al., 2005). There is a belief that education is a powerful engine by which individual gets an opportunity to move beyond their horizons. Thus education is an important and life-long process which helps in the development of overall personality of a human being. From independence up to this time India has achieved a lot in terms of educational progress at the macro level. 'Indian elementary education system has grown in size and complexity to become one of the largest in the world' (Vasavi, 2009). Among the members of vast Indian middle class education is seen as only the means of achieving greater equality, acquiring wealth and status by which they can overcome their drawbacks. Yet, there are several vulnerable communities which are still cut-off from the area of education and its benefits. By which many fail to appreciate the real importance of education. Thus this paper is examining the meaning and concerns about the value of education in one of the disadvantaged community in India.

Economists have long proposed a relationship between education and economic investment. But they failed to explain the educational outcomes which come through deliberate strategic investment in children by parents belonging to different social class. The works of Mincer (1962), Becker \& Chriswick (1966), Schultz (1964), Becker (1993), and Psacharopoulos \& Woodhall (1997) shows that formal education plays an instrumental role and is very important to increase the efficiency of productive activity in population. However, critiques raised a question that whether nations which have reached the highest rate in enrolment in schools and colleges have also reached the level of maximum productivity and equality? Study shows that even the nations which are having full enrolments with high educational expenditures also varied considerably in outcomes. For example, in India the university enrolment is three times higher than in Britain and equal to that in Western Europe (Psacharapoulos \& Hinchliffe, 1973) but at the same time the increasing number of educated unemployed in India is an alarming figure. 'The relatively high incidence of unemployment among the educated points up the economic waste involved in using scarce resources to educate and train young people (Malenbaum, 1957, p. 146). Rao (1966) in his work explained that the investment in education in many countries is not very fruitful due to rise in the number of educated unemployed. Thus the agenda to evaluate education in economic terms 
failed to explain the emerging trends of educated unemployed in many nations. The breakdown of this juncture shifts toward the understanding of the ways and processes underlying the education system. And this also explains why some communities have failed to see any meaning of education.

Several studies revealed that how young individuals, due to the inefficiency of education to fulfil its promises for economic security, started leaving schools and school identity and are looking towards back on the traditional work as the matter of their self-respect (Levinson, Foley, \& Holland, 1996; Demerath, 1999; Dreze and Sen, 1997; Sen, 2000; Willis, 1977 and Sarup, 1982). In India many youngsters especially in the lower caste and disadvantaged groups are unable to reap the benefits from education and its outcomes. 'Education has failed to open up the expanded employment and other substantive freedoms for young people across large swathes of the world' (Jeffrey, 2005, P. 8). In South Asian countries many young educated people failed to get secure salaried jobs and due to which they have to enter in many industrial manual menial jobs (Nieuwenhuys, 1994; Dyson, 2006). Thus education acts both as 'contradictory' and 'opportunity' resource which gives few the chances for mobilization and pushed many especially the disadvantaged section into the systems of social inequality (Levinson \& Holland, 1996; Dreze and Sen, 1997; Prause and Dooley; 1997, Apple, 1982; Bourdieu, 1984; Giroux, 2001 and Bourdieu \& Passeron, 1977).

There are other studies which show that in spite of disappointment in formal education and insecurity in regular salaried jobs many people especially in the disadvantaged communities still believe in the power of it. People believe that education is the only way by which they can have those skills and knowledge which can give them a label of modern man (Dreze \&Sen, 1995; Skinner \& Holland, 1996; Bara, 1997 and Jeffery et al., 2005). Education has also emerged as the source for the rise of new middle class among disadvantage sections. The rise of new and small 'middle class' amongst Chamars of Uttar Pradesh is the example of such an empowered group (Jefferlot, 2003).

With this it is also observed that the very process of schooling is not same for everyone. Variety of experiences and ways of learning in school shapes different perception of education. Thus different people hold different meanings to education and its values. One of the most interesting questions in comparative education is raised that why people are still believing in formal school education if it is not able to provide equal and adequate results to all (Stambach, 1998). The issue of power, social change and the meanings which people attached with education are still not adequately explained and is an urgent matter of an enquiry (Heyneman, 1980 \& 2004).

In today's time if education is not able to fulfil its promise of equality then with what hopes and expectations marginal and disadvantaged people are sending their children to schools? The meaning of education is very vast and relative but the general understanding in most of the cases is attached with enhanced potential for earnings, occupational mobility and status. Studies show that in spite of providing education to marginalise and downtrodden they are not able to extract more benefit out of it. And some studies show that sometimes education has a negative consequence on mobility. To explore these questions the present study is focusing on one of the Scheduled Castes communities named 'Mahasha' which is from the lowest rung of the Hindu caste hierarchy. They are also called as Doom, Doom, Doomna, Dumna, Dumne and registered in the Constitution of India (Scheduled Castes) Order, 1950. . The Mahasha or Doom/Dum of Jammu and Kashmir is also known as Jogi. They are among the lowest caste group and belong to the fourth and last Varna (Shudra) of the Hindu hierarchical System. The Dumna or Dum who have undergone purification process (shuddhi) organised by the Arya-Samaj are called the Mahasha (Singh, 1993 \& Das, 2007). Yet they are called by different names in different places with variety of traditional occupations which are normally labelled as impure menial jobs. This community is migrated from the India-Pakistan border due to emergency during "partition" and later permanently settled down in Jammu. The Community is a beneficiary of the "Land-Reform Act 1950" of J\&K. However they live in rather poor and pathetic conditions and have registered as the 'social and educationally backward caste' among all in Scheduled Caste Category of Jammu and Kahmir (2001, Census). Of late, they have started sending their children especially girls, to schools. The need of education to uplift them can be the perception of government and other scholars but what is their own perception about the necessity of education are the crucial aspects to understand. For this the insider's point of view that is the views of their own people, from their own community, is important to have answer for all raised questions.

\section{Theoretical Orientations}

Meanings can be understood as the 'intention' we want to convey. Meanings are generally used as "a correlate of individuals' intentions and considered a central element in contemporary accounts of knowledge formation" (Radford, 2006). "Edmund Husserl (one of Weierstrass' most brilliant students) endeavoured to understand how subjective intentions structure our awareness of what is being presented to us through our senses. Hence, meaning was elaborated 
as that which we intend" (ibid, 2006). Many of Edmund Husserl ideas were the inspiration for a number of contemporary aspects of phenomenological sociology. Especially the work of Alfred Schutz, the focal point of this tradition is on 'how people actively produce and sustain the meaning of situations' (Ritzer, 1992). Padma Sarangapani (2003) analysed in her work that people believe that education is the only option by which one can become modern. She argued that the knowledge which is given in the schools is constructed and far from the daily experiences of the children "Children understand the purpose of schooling as one of the opening up employment opportunities by providing the means for social mobility. They began to believe that by becoming literate, learning English and acquiring general knowledge, they will become socially adept and access the world of the 'educated man- the bada admi. This world includes desk job, steady income and self-respect. In contrast, the world of the illiterate- the anpadh- means hard manual work, low pay, insecurity and low status' (2003, p. 242).

Generally it assumes that people respond for something due to their subjective and personal views but sociologists explained that they are not just the free floating 'values' or expressions rather it is the result of continuous interaction and social practices. This further helps us to evaluate things from past and guide the future (Sayer, 2011). Kennneth Bruffe $(1972,1978,1984$ and 1986) has described that human's knowledge and human minds are basically socially created in which knowledge about something is created by social interaction. Thus the construction of perceptions, values or knowledge can be social and are shaped in specific context. "The physical world varies not only according to geographical location, but also according to different socio-economic and cultural locations" (Sarangapani, 2003). Knowledge and reality about something always possess specific characteristics. "The man in the street inhabits a world that is 'real' to him, albeit in different degrees, and he 'knows', with different degrees of confidence, that this world possesses such and such characteristics (Berger and Luckman, 1996). Further the actions and knowledge of human being continuously gets shape by the previous experiences and by the existing social circumstances. Thus social structure and social structural conditions puts immense impact on the creation of reality and perceptions with in some continuity.

\section{Situating the Mahashas: Reflections on Their Educational Values}

In contrast to number of studies done by scholars (Demerath, 1999; Levinson, 1996 ; Jeffrey, 2008) which showed that day by day poor and disadvantaged communities especially lower caste of society are losing faith in education and in its benefits, Mahashas are retaining it as the only source to have mobility in life. Historically the Mahashas are labelled as the backward in every aspect and they themselves kept very low level aspirations for their growth. They were devoid of education for long period of time and mainly remained occupied with menial jobs. Although there is a positive difference in the literacy level of their present generation as compared to the older ones. They have also showed their good numbers up to some extent like in almost everyone in present or young generation of their community possessed education up to middle class level (1-8 ${ }^{\text {th }}$ standard) but sudden dropped out after this level is alarming juncture for them.

\subsection{Aspirations and motivations}

From the field it has been found that Mahashas don't possess and are lacked in many characteristics and habits which can be the source of upward mobility for them. This can be called as 'cultural capital' in Bourdieu's sense. Bourdieu opined that the unequal stratified structure of the society can also be the source for less aspirations among disadvantaged which further sets the limits for them (Bourdieu, 1973). Thus aspirations are also based on the social, economic and cultural factors. It has been observed that members of Mahasha as community as compared to their previous generations are now fully motivated to send their children to schools. But the level of aspirations for level of studies and jobs are not found to be strong. For them girls having education up to $10^{\text {th }}$ standard is good and if some girls are able to complete up to $12^{\text {th }}$ standard is more than enough. But for boys their aspiration is found bit high like if boy is able to complete his studies up to $12^{\text {th }}$ standard is good and if he would go up to graduation level then it is enough in their community. With the low level of aspirations and motivation other aspect is also found for their backwardness and that is gender difference.

\subsection{Gender differences}

Among Mahashas sharp differences has been seen in the perceptions for value of education among men and women. And it is realized that the contrast can be due to the different life situations faced by men and women of Mahashas. After 
interview and with keen observations it has been realized that the experiences and meanings of education can produce different meanings in different individuals, sex or group. Meanings and values can be produced in the context of sociohistorical and individual's life situations.

Individual meanings for education are always given within social space which are significantly defined by community meanings related to generation, gender, residential area, and ethnic identity (Antikainen,A \& et al., 1999:8)

It has been observed that the condition of women of this community are worst than their counterparts. They are having very low literacy level as compared to men. But women are found to give more importance to education in spite of their low level of literacy. And the main reason for this was to have social security in future for children and for themselves. As majority of the male members of this community are engaged in unskilled daily wage menial jobs, followed by small petty own business and others. They constitute a low- income group and majority of them have meagre income to subsist up on. Madan (1969) in his study associate poverty with social disorganisation and opines that, "poor have a low income and it is difficult for them to manage the affairs of the family. Such people become discouraged and cannot perform their functions properly". With this majority of the female respondents experienced atrocities from their husbands. My field visits revealed that men from this community are also indulged in gambling, consuming alcohol and smoking too. After doing whole day work, when come back to home they often give $1 / 3 \mathrm{rd}$ of their income to wife and spend rest on their own enjoyment. One of the mother respondents said,

I want my child would have more and more study so that they can stand on their foot and in future get good job. My husband is just literate and I am fully illiterate. Whatever he earns, he spend more on his enjoyment outside home and leave meagre money to us. If my children would have good job tomorrow then my life would be automatically better. I don't have any hopes from my husband but do have from my children. 'Aaj kal padne likhne se hi sab kuch hota hai'( in today's time everything comes by education).

It is seen that for women, due to their unpleasant experiences in life, education is the only source for better future. They see education as the resource which can fulfil their social, cultural and economic demands. In contrast to women of this community for men education is more seen in terms of 'commodity'. They see more in terms of economic returns. Along with this for them 'market experience' is important after some level of schooling. The interaction with some men from their community is giving insights for their perception in following boxes:
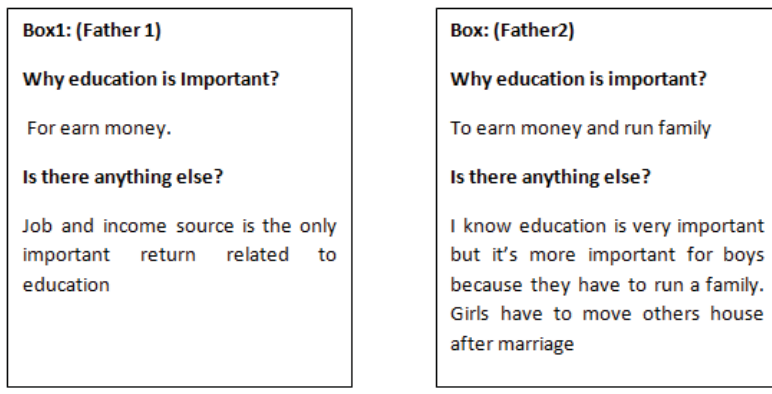

Besides this gender differences has been seen in the preferences for school for boys and girls. For them boys should have private education so that he can able to have all the knowledge of computer literacy and can speak and write English well. Due to the inefficiency of government schools to provide them necessary skills for securing jobs they labelled private schools as the best one. Secondly they prefer private education for boys due to the assumption that it will able their boys to have job in job market. And it is only the boys who are going to take care of them in their old age. Thus for them boys empowerment is necessary for their and his future thereby leaving girls to the government schools with a belief that girls have to move to other house after marriage.

\section{Conclusions}

Thus among Mahashas community it is seen that the morphology of the educational structure and unequal access has been changed with time. As the number of school going children has increased from the past but the process of 
morphogenesis is still the same and is continuously reproducing the unequal world. The social unequal structure in the society has profound inertia to reproduce inequality in the society through individual actions. It is closely examined that Mahashas meanings and belief system for education are widely shaped by their lived experiences and in relationship with others. They are not constructed and get shapes in the limitation of one time project rather it is reconstructing and getting new shapes and redesigning with course of time and according to need. Thus changes in the structural processes resulted into the change in meanings but the main agenda is remained same that has inequality.

\section{References}

Singh, K. (1993). The Scheduled Caste. (Vol. II). New Delhi: Oxford University Press.

Das, K. C. (2007). Global Encyclopaedia of the North Indians Dalits Ethnography. (Vol. 1). New Delhi: Global Vision Publishing House.

Jeffrey, C., Jeffrery, P., \& Jeffery, R. (2005). When schooling fails: Young men, education and low- caste politics in rural north India. Contributions to Indian Sociology, 39(1), 1-38.

Vasavi, A. R. (2009). New Imperatives for Elementary Education. Indian Journal of Human Development, 3(1), 133-142.

Bourdieu, P. (1986). The Forms of Capital. In Richardson, J. G. (Ed.), Handbook of Theory and Research for the Sociology of Education,New York: Greenwood Press, 241- 258..

Becker, G. S. (1993). Human Capital: A theoretical and Empirical analysis with special reference to education (3rd Ed.). London: The University of Chicago press.

Becker, G. S., \& Chriswick, B. R. (1966). Education and the Distribution of Earnings. American Economic Review, 56, 358- 369.

Mincer, J. (1962). On the Job Training: Costs, Returns, and Some Implications. Journal of Political Economy. 70(5).

Psacharopoulos, G., \& Woodhall, M. (1997). Education for Development: An Analysis of Investment Choice. New York: Oxford University Press.

Schultz, Theodore W. (1964). Education and values conducive to economic growth. Agricultural Policy Review, 2, 4 -6.

Psacharopoulos, G., \& Hinchliffe, K. (1973). Returns to Education- An International Comparison. San Francisco: Jossey- Bass.

Malenbaum. W. (1957). Urban unemployment in India. Pacific Affairs, 30, 139-151.

Rao. V. K. R. V. (1966). Education and human resource development. Bombay. New York: Allied Publishers.

Levinson, B. A., Foley, D. E., \& Holland, D. C. (Eds.). (1996). The cultural production of the educated person: Critical ethnographies of schooling and local practice. Albany, New York: State University of New York Press.

Demerath, P. (1999). The cultural Production of Educational Utility in Pere Village, Papua New Guinea. Comparative education Review, $43(2), 162-92$.

Dreze, J. \& Sen. A. (1997). Economic Development and Social Opportunity. Delhi: Oxford University Press.

Sen, A. (2000). Development as Freedom. Delhi: Oxford University Press.

Sarup, Madan. (1982). Education, State and Crisis. London: Routledge and Kegan Paul.

Willis, Paul. (1977). Learning to Labour: How Working class kids get working class jobs. Saxon House.

Nieuwenhuys, O. (1994). Children's Lifeworlds: Gender, Welfare and Labor in the Developing World. New York: Routledge

Dyson, J. (2006). Faces of the forest: Children's work in the Indian Himalayas. In Behera, D (Eds). Childhood in South Asia. Oxford: Pearson Education. 32-51.

Prause, J. \& Dooley, D. (1997). Effects of underemployment on school-leavers' self esteem. Journal of adolescence, 20(3), 243- 260.

Apple, M. (Ed.). (1982). Cultural and economic reproduction in education. London: Routledge Kegan and Paul.

Bourdieu, P. (1984). Distinction: A Social Critique of the Judgement of Taste. London: Routledge and Kegan Paul.

Bourdieu, P., \& Passeron, J. C. (1977). Reproduction in Education, Societies and Culture (R. Nice, Trans.). Beverly Hills, CA: Sage (1970).

Giroux, H. A. (2001). Theory and resistance in education: Towards pedagogy for the opposition (2nd Ed.). Westport, Conn. Bergin and Garvey.

Skinner, Debra and Dorothy Holland. (1996). Schools and the Cultural Production of the educated Person in a Nepalese Hill Community. In Bradley A. Levinson, Douglas E. Foley and Dorothy C. Holland (Eds.). The Cultural Production of the educated Person: Critical Ethnographies of Schooling and Local Practice. 272-300. Albany: State University of New York press.

Bara, Joseph. (1997). Western Education and the Rise of New identity: Mundas and Oraons of Chotanagpur. Economic and Political weekly, 32 (15), 1839-1939.

Jaffrelot, Christophe. (2003). India's Silent Revolution: the Rise of the Low Castes in North India. New York: Columbia University Press.

Stambach, Amy. (1998). Too much studying makes me crazy: School-related illness on Mount Kilimanjaro. Comparative Education Review. 42(4), 497-512.

Heyneman, Stephen P. (1980). Investment in Indian education: Uneconomic? World development. 8, 145.63. Retrieved from Academic Research Library database.

Heyneman, Stephen. P. (2004). International education Quality. Economic of Education Review. 23, 441-452. doi: 10.1016/j.econedurev.2003.10.002.

Radford. L. (2006). The Anthropology of meaning. Educational Studies in Mathematics. 61, 39-65. doi: 10.1007/s10649-006-7136-7.

Ritzer, George. (1992). Sociological Theory (3rd Ed.). Place: McGraw- Hill Co.

Sarangapani, P. (2002). Constructing School Knowledge: an ethnography of learning in Indian village. California: Sage publications. 
Sayer, Andrew. (2011). Why things matter to people: Social Science, Values and Ethical Life. Cambridge University Press. New York. Bruffe, Kenneth. (1972). Collaborative Learning: Some Practical Models. College English, 34.

(1984). Collaborative Learning and 'The Conversation of Mankind. College English, 46.

(1986). Social Construction, Language, and the Authority of Knowledge: A Bibliographical Essay. College English, 48.

Antikainen, A., Houtsonen, J., Kauppila, J., Komonen, K., Koski, L., and Kayhko, M. (1999). Construction of Identity and Culture Through education. International Journal of Contemporary Sociology. 36 (2), 204-228. 